\title{
The Point Mutation G461S in the MfCYP51 Gene is Associated with Tebuconazole Resistance in Monilinia fructicola Populations in Brazil
}

\author{
Paulo S. F. Lichtemberg, Yong Luo, Rafael G. Morales, Juliana M. Muehlmann-Fischer, Themis J. Michailides, \\ and Louise L. May De Mio ${ }^{\dagger}$
}

First, second, and fifth authors: Department of Plant Pathology, University of California, Davis and Kearney Agricultural Research and Extension Center, 9240 S Riverbend Ave., Parlier, CA 93648; third and sixth authors: Department of Plant Pathology, Universidade Federal do Paraná, Curitiba, PR, 80035-050, Brazil; and fourth author: Department of Genetics, Universidade Federal do Paraná, Curitiba, PR, 81531990, Brazil.

Accepted for publication 11 July 2017.

\begin{abstract}
The ascomycete Monilinia fructicola is the causal agent of brown rot of stone fruit in Brazil, causing major pre- and postharvest losses. For many years, the demethylation inhibitor (DMI) fungicide tebuconazole has been used as the most effective active ingredient for controlling brown rot and, as a result, strains of $M$. fructicola resistant to this ingredient have emerged in many Brazilian states producing stone fruit. The aim of this study was to investigate the mechanisms associated with the resistance of $M$. fructicola to DMI tebuconazole. By sequencing the M. fructicola CYP51 (MfCYP51) gene, encoding the azole target sterol $14 \alpha$-demethylase, a mutation was identified at the nucleotide position 1,492, causing the amino acid substitution from glycine to serine at the codon position 461, associated with

reduced tebuconazole sensitivity. In addition, it was observed that MfCYP51 gene expression could play a secondary role in DMI fungicide resistance of M. fructicola strains in Brazil. However, for the specific isolate found to exhibit elevated expression levels of MfCYP51, no insertions that would trigger gene expression were found. Based on the point mutation associated with tebuconazole resistance, an allele-specific polymerase chain reaction method was developed to quickly identify resistant genotypes within the Brazilian population. This is the first report determining molecular mechanisms for DMI resistance identification for M. fructicola isolates from Brazil. This information provides an important advancement for risk assessment of DMI fungicides used to manage brown rot of stone fruit.
\end{abstract}

The sterol demethylation inhibitor (DMI) fungicides are the largest and most important group of antifungal agents used in agriculture (Oliver and Hewitt 2014). The broad spectrum of fungicidal activity and their systemic distribution make the DMI fungicides the most popular chemical group used in a wide range of crops to control important fungal diseases (Ziogas and Malandrakis 2015). DMI inhibits the $\mathrm{C} 14$-demethylation step of the ergosterol biosynthesis by binding to the heme iron of the cytochrome P450, leading to the accumulation of toxic sterols that exert a severe stress on the cell membrane (Kelly and Kelly 2013; Lupetti et al. 2002; Oliver and Hewitt 2014; Shapiro et al. 2011; Ziogas and Malandrakis 2015). For more than 30 years, this chemical group has been widely used to control Monilinia spp., causing blossom blight and fruit rot in stone fruit around the world (Batra 1991; Chen et al. 2013). As a result of its overuse, DMI-fungicide resistance arose and has been reported in many countries (Amiri et al. 2010; Chen et al. 2013; Elmer et al. 1992; May De Mio et al. 2011; Schnabel et al. 2004; Zehr et al. 1999).

Different molecular mechanisms acting individually or in combination were reported to be associated with altered DMI sensitivity in many fungal pathogens. The most common mechanisms include target-site modification (Cools et al. 2013; Délye et al. 1997; Mann et al. 2003; Nikou et al. 2009; Wyand and Brown 2005), overexpression of C14-demethylase (Carter et al. 2014; Doukas et al. 2012; Hamamoto et al. 2000; Ma et al. 2006; Schnabel and Jones 2001), and increased energy-dependent fungicide efflux (Doukas et al. 2012; Leroux and Walker 2013; Nakaune et al. 1998; Zwiers et al. 2002). In Monilinia fructicola isolates from the United States, the DMI resistance mechanism is mostly attributed to the overexpression of $M$. fructicola CYP51 (MfCYP51) gene, which encodes the 14 $\alpha$-demethylase, the

†Corresponding author: L. L. May De Mio; E-mail: maydemio@ufpr.br

C 2017 The American Phytopathological Society target of DMI fungicides (Luo and Schnabel 2008). In the same study, these authors found that resistant isolates were associated with the presence of a 65-bp inserted sequence designated genetic element Mona, located at the upstream region of the MfCYP51 gene. In the same year, Luo et al. (2008) reported the development of a polymerase chain reaction (PCR)-based assay to quickly identify isolates carrying the Mona element throughout the United States. As a result, the Mona element was identified not only in isolates of M. fructicola in Georgia but also in isolates in South Carolina, Ohio, New Jersey, and New York State (Burnett et al. 2010; Luo et al. 2008; Villani and Cox 2011). However, the absence of Mona in some isolates showing reduced sensitivity to propiconazole in New York State indicated that the overexpression of MfCYP51 gene could be triggered by promoters other than Mona, or even the presence of a secondary mechanism (Villani and Cox 2011). Also in the United States, studies have shown that $M f A B C l$ gene was overexpressed after isolates have been treated with a nonlethal dose of myclobutanil and propiconazole separately, suggesting that $M f A B C 1$ may play a secondary role in DMI fungicide resistance (Luo and Schnabel 2008; Schnabel et al. 2003). A third mechanism conferring DMI resistance in $M$. fructicola isolates was described in China, where DMI-resistant isolates were associated with a single-nucleotide polymorphism causing an amino acid change from tyrosine to phenylalanine at the codon position 136 (Y136F mutation) in the MfCYP51 gene that encodes the target protein for DMI fungicides (Chen et al. 2012).

In Brazil, many efforts have been made to monitor the development of DMI fungicide resistance in isolates of $M$. fructicola (Lichtemberg et al. 2016b; May De Mio et al. 2011). However, the molecular mechanisms conferring this resistance in Brazilian populations are still unknown, impairing our knowledge of determinant factors affecting the population dynamics of the resistant strains and the planning of antiresistance strategies (Lichtemberg et al. 2016a). Therefore, the objectives of this study were to (i) characterize the molecular mechanisms of DMI resistance in M. fructicola from Brazil and (ii) develop a sensitive method to identify resistant genotypes. 


\section{MATERIAL AND METHODS}

All isolates were obtained from commercial stone fruit orchards (mummified fruit) located in São Paulo, Paraná, Santa Catarina, and Rio Grande do Sul States of Brazil. Pure isolate cultures were identified as $M$. fructicola according to methods described by Côté et al. (2004). The effective concentration to inhibit $50 \%$ of the mycelial growth $\left(\mathrm{EC}_{50}\right.$ value) of these isolates were obtained from previous publications (Table 1).

The presence of Mona element. In total, 58 isolates (Table 1) were tested for the presence of the Mona element. Isolates were grown on acidified potato dextrose agar (APDA) $(2.5 \mathrm{ml}$ of $25 \%$ lactic acid [wt/vol]) (Microtech Scientific, Orange, CA) covered with a cellophane disc for 5 days at $24^{\circ} \mathrm{C}$ with a 12 -h light regime. Genomic DNA was extracted from $2 \mathrm{~cm}^{2}$ of mycelium, using the UltraClean Microbial DNA extraction kit (MoBio Laboratories,
Solana, CA) following the manufacturer's protocols. The genomic DNA of the resistant isolate Bmpc7 from Georgia (in the United States), was kindly provided by Professor Guido Schnabel (Clemson University, Clemson, SC) and used as positive control due to the presence of the Mona element (Luo et al. 2008).

The primers INS65-F and INS65-R (primer set 1) (Table 2) were designed to amplify the upstream region of the gene MfCYP51, resulting in a 376-bp fragment in isolates carrying the Mona element and a 311-bp in isolates in which Mona is absent (Luo et al. 2008). The PCR for $25 \mu \mathrm{l}$ included $20 \mathrm{ng}$ of genomic DNA, $0.5 \mu \mathrm{M}$ each primer, $200 \mu \mathrm{M}$ each dNTP, and $0.625 \mathrm{U}$ of Taq DNA polymerase (Invitrogen, Carlsbad, CA). Amplifications were performed in an iCycler thermal cycler (Bio-Rad Laboratories, Hercules, CA) programmed for $3 \mathrm{~min}$ at $94^{\circ} \mathrm{C} ; 30$ cycles of $1 \mathrm{~min}$ at $94^{\circ} \mathrm{C}, 1 \mathrm{~min}$ at $60^{\circ} \mathrm{C}$, and $1 \mathrm{~min}$ at $72^{\circ} \mathrm{C}$; and followed by a final extension step of $5 \mathrm{~min}$ at $72^{\circ} \mathrm{C}$. The PCR products were stained with GelRed (Invitrogen) and separated on a

TABLE 1. Isolates of Monilinia fructicola used in this study and their background information

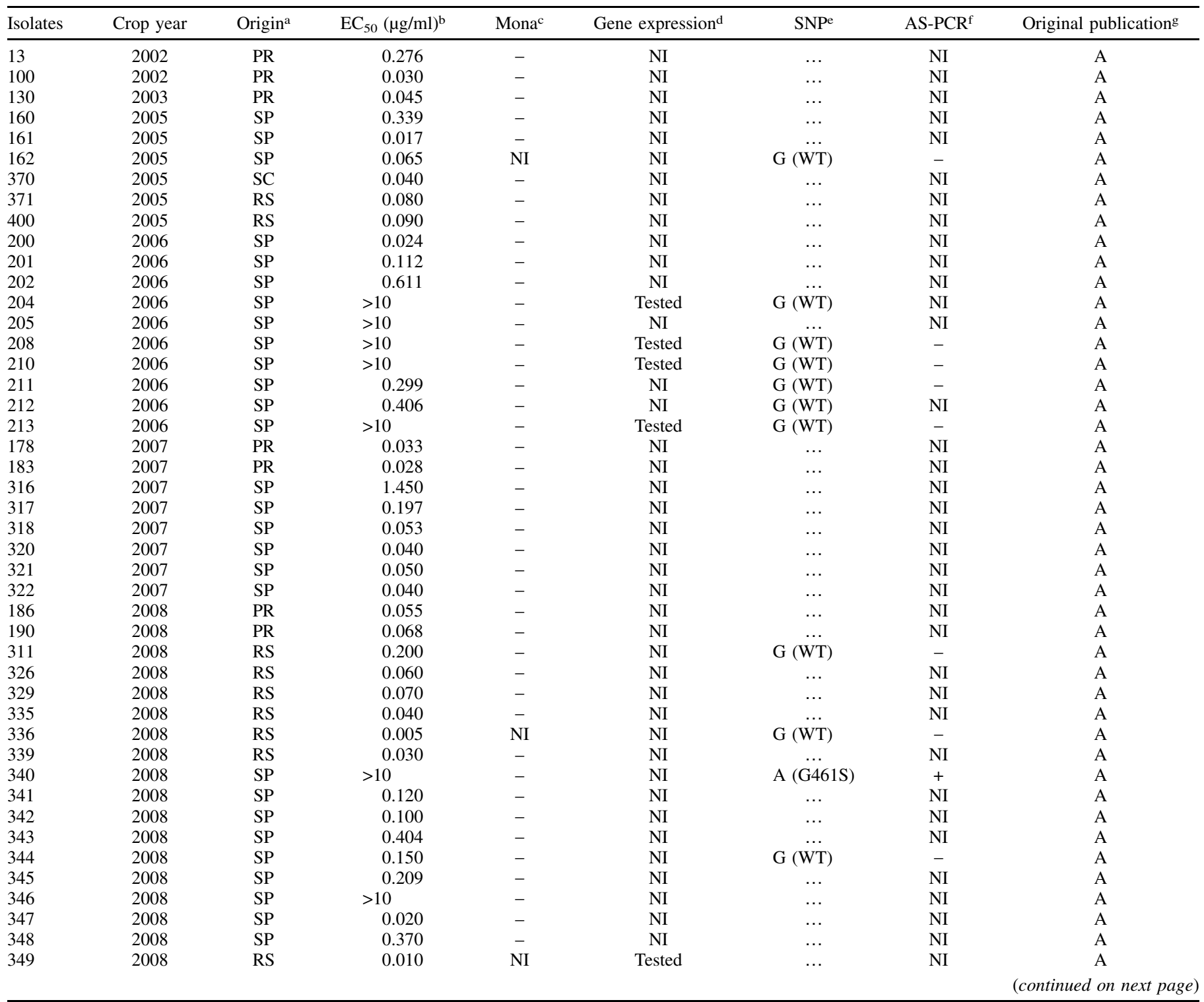

a Place of origin where isolate was collected: São Paulo (SP), Paraná (PR), Santa Catarina (SC), and Rio Grande do Sul State (RS).

b Original 50\% effective concentration $\left(\mathrm{EC}_{50}\right)$ value, measured at the collection year by the author described in the original publication column.

${ }^{c}$ Isolates tested for the presence of the Mona element $(n=58)$ : negative for Mona $(-)$ or not investigated (NI).

${ }^{\mathrm{d}}$ Isolates tested for MfCYP51 and MfABC1 gene expression $(n=10)$. NI $=$ not investigated.

e Single-nucleotide polymorphism (SNP) at position 1,492 of MfCYP51 Isolates sequenced for MfCYP51 gene $(n=59)$ at nucleotide position 1,492 in wild-type G (WT) and mutant A (G498S) or not investigated (NI).

f Allele-specific polymerase chain reaction (AS-PCR) 178-bp band for G461S mutant $(n=56)$. Symbols: wild type $(-)$, mutant $(+)$, and not investigated (NI). g A = May De Mio et al. (2011), B = Lichtemberg et al. (2016a), and C = this study. 
$1.5 \%$ agarose gel at $100 \mathrm{~V}$ for $1 \mathrm{~h}$. DNA ladder TrackIt (Invitrogen) was used. Presence or absence of the Mona element was confirmed by digesting the PCR product with the restriction endonuclease BsrBI. Only fragments containing Mona are digestible with this enzyme, resulting in two restriction fragments of 236 and 140 bp in size (Luo et al. 2008). PCR fragments were submitted to restriction digestions with $B s r$ BI (FastDigest MbiI; Thermo Scientific, Waltham, MA) at $37^{\circ} \mathrm{C}$ for $10 \mathrm{~min}$, according to the manufacturer's recommendations. Digested PCR products were separated on a $1.5 \%$ agarose gel and visualized in UV light. The PCR assay and PCR product digestion with restriction endonuclease $B s r \mathrm{BI}$ were repeated.

Sequencing of isolates 21, 152, 316, 202, and 340 amplified with primer set 1 were performed at the UFPR Sequencing Facility (Curitiba, Brazil) in order to confirm the results obtained with the enzyme
BsrBI. PCR products were purified with ammonium acetate and ethanol (Crouse and Amorese 1987). Sequence editing and inspection were performed using the BioEdit program, version 7.0 (Hall 2004), while alignment and GenBank comparison using the accession number EU035301 (Luo and Schnabel 2008) were performed with the BLAST program (Altschul et al. 1997).

MfCYP51 and $\boldsymbol{M} \boldsymbol{f A B C 1}$ gene expression. This experiment included 10 isolates, described in Table 1 . The mycelial preparation started by culturing isolates on APDA plates covered with a cellophane disc and incubated for 5 days at $24^{\circ} \mathrm{C}$ with a 12-h light regime. The protocol used was the same described by Schnabel et al. (2003), with modifications, where $1 \mathrm{~cm}^{2}$ of a 5-day-old mycelium was transferred into $250-\mathrm{ml}$ flasks (two flasks per isolate) with $50 \mathrm{ml}$ of acidified potato dextrose broth $(2.5 \mathrm{ml}$ of $25 \%$ lactic acid [wt/vol] $)$,

TABLE 1. (continued from preceding page)

\begin{tabular}{|c|c|c|c|c|c|c|c|c|}
\hline Isolates & Crop year & Origin $^{a}$ & $\mathrm{EC}_{50}(\mu \mathrm{g} / \mathrm{ml})^{\mathrm{b}}$ & Mona $^{c}$ & Gene expression $^{\mathrm{d}}$ & $\mathrm{SNP}^{\mathrm{e}}$ & AS-PCR ${ }^{f}$ & Original publication ${ }^{\mathrm{g}}$ \\
\hline 502 & 2008 & $\mathrm{SC}$ & 0.100 & - & NI & $\ldots$ & $\mathrm{NI}$ & A \\
\hline 508 & 2008 & SC & 0.073 & - & NI & $\ldots$ & NI & A \\
\hline 528 & 2008 & $\mathrm{SC}$ & 0.059 & - & $\mathrm{NI}$ & $\ldots$ & $\mathrm{NI}$ & A \\
\hline 538 & 2008 & $\mathrm{SC}$ & 0.012 & - & $\mathrm{NI}$ & $\ldots$ & $\mathrm{NI}$ & A \\
\hline 546 & 2008 & $\mathrm{SC}$ & 0.020 & - & $\mathrm{NI}$ & $\ldots$ & $\mathrm{NI}$ & A \\
\hline 558 & 2008 & SC & 0.031 & - & NI & $\ldots$ & NI & A \\
\hline 646 & 2009 & PR & 0.001 & NI & NI & $\mathrm{G}(\mathrm{WT})$ & - & B \\
\hline 754 & 2009 & SP & 0.374 & NI & NI & A (G461S) & + & B \\
\hline 761 & 2009 & SP & 0.532 & NI & NI & A (G461S) & + & B \\
\hline 940 & 2009 & SP & 0.403 & NI & NI & A (G461S) & + & B \\
\hline 951 & 2009 & SP & 0.283 & NI & NI & A (G461S) & + & B \\
\hline 1020 & 2010 & $\mathrm{RS}$ & 0.079 & NI & NI & $\mathrm{G}(\mathrm{WT})$ & - & B \\
\hline 1023 & 2010 & PR & 0.003 & NI & NI & G (WT) & - & B \\
\hline 1069 & 2010 & PR & 0.061 & $\mathrm{NI}$ & $\mathrm{NI}$ & G (WT) & - & B \\
\hline 1099 & 2010 & SP & 0.004 & $\mathrm{NI}$ & $\mathrm{NI}$ & G (WT) & - & B \\
\hline 10 & 2011 & PR & 0.040 & - & NI & $\ldots$ & NI & B \\
\hline 15 & 2011 & PR & 0.480 & NI & Tested & A (G461S) & + & B \\
\hline 21 & 2011 & PR & 0.008 & - & $\mathrm{NI}$ & $\mathrm{G}(\mathrm{WT})$ & - & B \\
\hline 25 & 2011 & PR & 0.016 & NI & NI & $\mathrm{G}(\mathrm{WT})$ & - & B \\
\hline 35 & 2011 & PR & 0.002 & - & NI & $\ldots$ & NI & B \\
\hline 39 & 2011 & PR & 0.009 & - & NI & $\ldots$ & NI & B \\
\hline 106 & 2011 & PR & 0.003 & NI & Tested & G (WT) & - & B \\
\hline 107 & 2011 & RS & 0.010 & $\mathrm{NI}$ & NI & G (WT) & - & B \\
\hline 110 & 2011 & RS & 0.003 & - & NI & $\ldots$ & NI & B \\
\hline 112 & 2011 & RS & 0.014 & - & NI & $\mathrm{G}(\mathrm{WT})$ & - & B \\
\hline 113 & 2011 & $\mathrm{RS}$ & 0.029 & NI & NI & $\mathrm{G}(\mathrm{WT})$ & - & B \\
\hline 115 & 2011 & RS & 0.036 & - & $\mathrm{NI}$ & G (WT) & - & B \\
\hline 122 & 2011 & $\mathrm{RS}$ & 0.039 & - & NI & $\mathrm{G}(\mathrm{WT})$ & - & B \\
\hline 126 & 2011 & RS & 0.003 & - & NI & $\mathrm{G}(\mathrm{WT})$ & - & B \\
\hline 134 & 2011 & RS & 0.087 & NI & NI & G (WT) & - & B \\
\hline 152 & 2011 & SP & 0.689 & - & NI & A (G461S) & + & B \\
\hline 158 & 2011 & SP & 0.490 & $\mathrm{NI}$ & $\mathrm{NI}$ & A (G461S) & + & B \\
\hline 203 & 2011 & SP & 0.131 & NI & $\mathrm{NI}$ & A (G461S) & + & B \\
\hline 802 & 2011 & SP & 0.334 & NI & Tested & A (G461S) & + & B \\
\hline 807 & 2011 & SP & 1.164 & NI & Tested & A (G461S) & + & B \\
\hline 945 & 2011 & SP & 0.409 & $\mathrm{NI}$ & Tested & A (G461S) & + & B \\
\hline $\mathrm{c} 1$ & 2015 & SP & 0.231 & NI & NI & A (G461S) & + & $\mathrm{C}$ \\
\hline $\mathrm{c} 10$ & 2015 & SP & 0.204 & NI & NI & A (G461S) & + & $\mathrm{C}$ \\
\hline c14 & 2015 & SP & $>15.625$ & NI & NI & A (G461S) & + & $\mathrm{C}$ \\
\hline c19 & 2015 & SP & 0.161 & $\mathrm{NI}$ & $\mathrm{NI}$ & A (G461S) & + & $\mathrm{C}$ \\
\hline $\mathrm{c} 23$ & 2015 & SP & 0.419 & $\mathrm{NI}$ & $\mathrm{NI}$ & A (G461S) & + & $\mathrm{C}$ \\
\hline c24 & 2015 & SP & 0.022 & $\mathrm{NI}$ & $\mathrm{NI}$ & $\mathrm{G}(\mathrm{WT})$ & - & $\mathrm{C}$ \\
\hline $\mathrm{c} 25$ & 2015 & SP & 0.399 & NI & $\mathrm{NI}$ & A (G461S) & + & $\mathrm{C}$ \\
\hline c26 & 2015 & SP & 0.429 & NI & $\mathrm{NI}$ & A (G461S) & + & $\mathrm{C}$ \\
\hline c3 & 2015 & SP & 0.012 & $\mathrm{NI}$ & $\mathrm{NI}$ & $\mathrm{G}(\mathrm{WT})$ & - & $\mathrm{C}$ \\
\hline c30 & 2015 & SP & 0.016 & NI & NI & $\mathrm{G}(\mathrm{WT})$ & - & $\mathrm{C}$ \\
\hline c31 & 2015 & SP & 0.475 & NI & NI & A (G461S) & + & $\mathrm{C}$ \\
\hline c33 & 2015 & SP & 4.835 & NI & NI & A (G461S) & + & $\mathrm{C}$ \\
\hline c44 & 2015 & SP & 0.370 & NI & NI & A (G461S) & + & $\mathrm{C}$ \\
\hline c58 & 2015 & SP & $>15.625$ & $\mathrm{NI}$ & $\mathrm{NI}$ & A (G461S) & + & $\mathrm{C}$ \\
\hline c64 & 2015 & SP & 1.190 & $\mathrm{NI}$ & $\mathrm{NI}$ & A (G461S) & + & $\mathrm{C}$ \\
\hline c66 & 2015 & SP & 0.019 & NI & $\mathrm{NI}$ & G (WT) & - & $\mathrm{C}$ \\
\hline c79 & 2015 & SP & 0.041 & NI & $\mathrm{NI}$ & $\mathrm{G}(\mathrm{WT})$ & - & $\mathrm{C}$ \\
\hline c86 & 2015 & SP & 0.475 & $\mathrm{NI}$ & $\mathrm{NI}$ & A (G461S) & + & $\mathrm{C}$ \\
\hline s41 & 2015 & SP & 0.495 & NI & NI & A (G461S) & + & $\mathrm{C}$ \\
\hline s43 & 2015 & SP & 0.602 & $\mathrm{NI}$ & $\mathrm{NI}$ & A (G461S) & + & $\mathrm{C}$ \\
\hline$s 45$ & 2015 & SP & 0.745 & NI & NI & A (G461S) & + & $\mathrm{C}$ \\
\hline s 48 & 2015 & SP & 0.230 & NI & NI & A (G461S) & + & $\mathrm{C}$ \\
\hline
\end{tabular}


(Microtech Scientific). Additionally, the liquid cultures were incubated for 4 days at $24 \pm 1^{\circ} \mathrm{C}$ on a rotary shaker at $100 \mathrm{rev} / \mathrm{min}$. At the fourth day of growth, prior to the RNA extraction, in one of two flasks per isolate, DMI tebuconazole at $0.5 \mu \mathrm{g} / \mathrm{ml}$ (Folicur 3.6F; Bayer CropScience, Durham, NC) suspended with dionized sterile water was added and incubated for $1 \mathrm{~h}$. Untreated growing cultures (controls) were not exposed to fungicide.

The total RNA was extracted from $100 \mathrm{mg}$ of dried mycelial pellets, harvested on filter paper by suction (Whatman number 1; Maidstone, England). To extract RNA, the FastRNA Pro Red kit (MP Biomedicals, Solon, $\mathrm{OH}$ ) was used, with the FastPrep Instrument (MP Biomedicals) programmed for $40 \mathrm{~s}$ at a speed setting of 6.0. Concentration was readily checked using a NanoDrop 1000 Spectrophotometer (Fischer Scientific, Pittsburgh). Integrity was checked using a 1.5\% formaldehyde agarose gel, with samples stained with GelRed (Invitrogen) and RNA $2 \times$ sample Loading Buffer (Invitrogen).

The cDNA was synthesized with the GoScript Reverse-Transcription System (Promega Corp., Madison, WI) following the manufacturer's protocol, with modifications. For a $20-\mu \mathrm{l}$ reaction, $2 \mu \mathrm{l}$ of experimental RNA at $500 \mathrm{ng} / \mu \mathrm{l}$ and $1 \mu \mathrm{l}$ of primer Oligo $(\mathrm{dT})_{15}$ were used. The reverse-transcription reaction mix included $3.2 \mu \mathrm{l}$ of $0.4 \mathrm{mM} \mathrm{MgCl}_{2}$. The synthesized cDNA was used to amplify a 176bp fragment of the gene $M f A B C 1$ with the primer pair MfABC6-F and MfABC6-R (primer set 2), designed from the GenBank accession number AY077839 (Schnabel et al. 2003), and 120 bp of the gene MfCYP51 with primers RealCYP-F2 and RealCYP-R2 (primer set 3), retrieved from Luo and Schnabel (2008) (Table 2). The $25-\mu l$ reaction included $12.5 \mu \mathrm{l}$ of PCR Master Mix (Promega Corp.), $2 \mu \mathrm{l}$ of experimental cDNA at $5 \mathrm{ng} / \mu \mathrm{l}, 0.5 \mu \mathrm{l}$ of each primer at $10 \mathrm{mM}$, and nuclease-free water. The PCR protocol used consisted of one cycle of $94^{\circ} \mathrm{C}$ for $2 \mathrm{~min} ; 40$ cycles of $94^{\circ} \mathrm{C}$ for $30 \mathrm{~s}, 52^{\circ} \mathrm{C}$ for 30 $\mathrm{s}$, and $72^{\circ} \mathrm{C}$ for $20 \mathrm{~s}$; and a final extension step of $72^{\circ} \mathrm{C}$ for $5 \mathrm{~min}$. A thermocycler (Eppendorf Mastercycle, Hamburg, Germany) was used. PCR product was visualized on $1.5 \%$ formaldehyde agarose gel, with samples stained with GelRed (Invitrogen) and DNA ladder TrackIt (Invitrogen). PCR products were purified with ExoSAP-it (Affymetrix Inc., Cleveland, $\mathrm{OH}$ ), following the manufacturer's protocol. Purified reactions were submitted for sequencing at the University of California, Davis (UC-Davis) Sequencing Facility. Sequence editing, inspection, and alignment were performed using the BioEdit program (version 7.0) (Hall 2004). Primers created for this study were designed with the open software Primer3 (v.0.4.0) (Koressaar and Remm 2007; Untergasser et al. 2012).

To quantify the expression of the genes MfCYP51 and MfABC1, real-time PCR amplification was performed with the DNA Engine
Opticon 2 system (MJ Research, Waltman, MA) using the GoTaq qPCR Master Mix (Promega Corp.) containing BRYT Green as a fluorescent DNA-binding dye. Each reaction was performed in $25-\mu \mathrm{l}$ volumes containing $2 \mu \mathrm{l}$ of cDNA template at $5 \mathrm{ng} / \mu \mathrm{l}, 12.5 \mu \mathrm{l}$ of GoTaq qPCR Master Mix, $0.5 \mu \mathrm{l}$ of each primer at $10 \mu \mathrm{M}$, and filled up with nuclease-free water. The primer pair MfActin-F/MfActin-R (primer set 4) (Table 2) was used to amplify an 85-bp fragment of the MfActin gene (Schnabel and Dai 2004) and normalize the expression quantification of the target genes. All PCR were amplified in quadruplicate using the following program: 1 cycle of $95^{\circ} \mathrm{C}$ for $3 \mathrm{~min}, 40$ cycles of $95^{\circ} \mathrm{C}$ for $10 \mathrm{~s}$ and $55^{\circ} \mathrm{C}$ for $45 \mathrm{~s}$, and 1 cycle of $95^{\circ} \mathrm{C}$ for $1 \mathrm{~min}$ and $55^{\circ} \mathrm{C}$ for $1 \mathrm{~min}$. To confirm the correct amplification in these reactions, a melting curve was constructed for each PCR (100 cycles, increasing temperature by $0.4^{\circ} \mathrm{C}$ increments starting at $55^{\circ} \mathrm{C}$ ) to verify the presence of the peak of the melting curve specific to the expected target PCR product without the presence of primer dimmer.

In order to determine the fold change in expression of the genes $M f C Y P 51$ and MfABCl of isolates exposed to tebuconazole, the comparative cycle threshold $(\mathrm{Ct})$ method or $2^{-\Delta \Delta \mathrm{Ct}}$ method (separate tubes) was chosen, using the MfActin expression to normalize data (Livak and Schmittgen 2001). The assumptions to use the comparative $\mathrm{Ct}$ method for gene expression quantification was validated by the equal efficiency of the target and reference amplification for genes $M f A B C l$ (slope $=0.0208$ ) and $M f C Y P 51$ (slope $=0.057)$ (data not shown). To calculate the related gene expression $M f C Y P 51$ and $M f A B C 1$, the following equation was used:

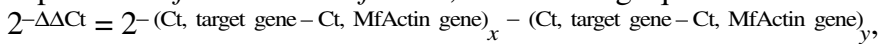
where $x$ is the tebuconazole treated sample and $y$ is the untreated isolate sample, used as calibrator. The result was interpreted as the fold expression obtained with fungicide at $0.5 \mu \mathrm{g} / \mathrm{ml}$ in relation to dose 0 (without fungicide), as detailed in example 1 from Schmittgen and Livak (2008). All experiments were repeated.

Partial sequencing of the MfCYP51 gene. Genomic DNA of each the of $59 \mathrm{M}$. fructicola isolates was extracted from mycelium using the FastDNA Kit (MP Biomedicals), with the FastPrep Instrument (MP Biomedicals) programmed for $40 \mathrm{~s}$ at a speed setting of 6.0. Mycelium was scraped off the surface of a 5-day-old growing culture on PDA covered with cellophane paper incubated at $24^{\circ} \mathrm{C}$ with a 12-h light regime. In order to amplify the MfCYP51 gene, four primer pairs were designed from the GenBank accession number GU136400 (Chen et al. 2012). The primer pairs MfCYPbr1F/ MfCYPbr1R (primer set 5), MfCYPbr2F/MfCYPbr2R (primer set 6), MfCYPbr3F/MfCYPbr3R (primer set 7), and MfCYPbr4F/ MfCYPbr4R (primer set 8) were able to amplify overlapping fragments of the target gene MfCYP51 (Table 2). PCR of $20 \mu \mathrm{l}$ in volume

TABLE 2. Primer pairs used in this study

\begin{tabular}{|c|c|c|c|c|c|}
\hline \multirow[b]{2}{*}{ Set } & \multirow[b]{2}{*}{ Primer } & \multirow[b]{2}{*}{$5^{\prime}$ to $3^{\prime}$ sequence } & \multicolumn{2}{|c|}{ Length (bp) } & \multirow[b]{2}{*}{ Citation } \\
\hline & & & Primer & Product & \\
\hline \multirow[t]{2}{*}{1} & INS65-F & TCGATGTTGCGTGGTCTGTCA & 21 & 376 & Luo et al. (2008) \\
\hline & INS65-R & CGGAGAGCGTCGATGTAGGTG & 21 & $\ldots$ & $\ldots$ \\
\hline \multirow[t]{2}{*}{2} & MfABC6-F & GCCAACAATCGAGCGGGATA & 20 & 176 & This study ${ }^{\mathrm{a}}$ \\
\hline & MfABC6-R & GGACCCTTCATTCTGGTCGC & 20 & $\ldots$ & $\ldots$ \\
\hline \multirow[t]{2}{*}{3} & RealCYP-F2 & TCTTGGGCGCCGACCTTC & 19 & 120 & Luo and Schnabel (2008) \\
\hline & RealCYP-R2 & CTTTGCGCATGATAGAGTGGAT & 22 & $\ldots$ & $\ldots$ \\
\hline \multirow[t]{2}{*}{4} & MfActin-F & GTGTTGATATGGCCGGTCGTGATT & 24 & 85 & Schnabel and Dai (2004) \\
\hline & MfActin-R & TCGGCAGTGGTGGAGAAAGTGTAA & 24 & $\ldots$ & \\
\hline \multirow[t]{2}{*}{5} & MfCYPbr1F & AAGAGATTTCGCAGCGGTCTA & 21 & 518 & This study ${ }^{\mathrm{a}}$ \\
\hline & MfCYPbr1R & CTGTTGCAGCGTCATCAGTT & 20 & $\ldots$ & \\
\hline \multirow[t]{2}{*}{6} & MfCYPbr2F & AAAGGGCAACGACTTTATTCTC & 22 & 473 & This study \\
\hline & MfCYPbr2R & GAGGAGCCCAATGAAGCATA & 20 & $\ldots$ & 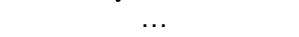 \\
\hline \multirow[t]{2}{*}{7} & MfCYPbr3F & AAAAGGGAACTGCCAATATTCC & 22 & 578 & This study ${ }^{\mathrm{a}}$ \\
\hline & MfCYPbr3R & GTGGATGGGAGTGTGGAGA & 19 & $\ldots$ & \\
\hline \multirow[t]{2}{*}{8} & MfCYPbr4F & AAATATGAGGACTTGTCCAAACTTA & 25 & 516 & This study ${ }^{a}$ \\
\hline & MfCYPbr4R & TCTCTCCCATGCCACAACAG & 20 & $\ldots$ & \\
\hline \multirow[t]{2}{*}{9} & MfgaF1 & AGCCСТTACСТTCССАТTA & 19 & 178 & This study ${ }^{a}$ \\
\hline & MfgaR1 & GCTCCAATGGTCTCGTGAAT & 20 & $\ldots$ & ... \\
\hline
\end{tabular}

a Primers used in this study were designed on Primer (v.0.4.0) (http://primer3.sourceforge.net/). 
used the Accupower PCR premix Tube (Bioneer, Alameda, CA) containing $2 \mu \mathrm{l}$ of DNA template at $5 \mathrm{ng} / \mu \mathrm{l}, 0.5 \mu \mathrm{l}$ of each primer pair at $10 \mu \mathrm{M}$, and $17 \mu \mathrm{l}$ of Dnase-free water. Amplifications were performed in a thermocycler (Eppendorf Mastercycle) programmed for $4 \mathrm{~min}$ at $95^{\circ} \mathrm{C} ; 32$ cycles of $30 \mathrm{~s}$ at $95^{\circ} \mathrm{C}, 30 \mathrm{~s}$ at $58^{\circ} \mathrm{C}$, and $2 \mathrm{~min}$ at $72^{\circ} \mathrm{C}$; followed by a final extension step of $10 \mathrm{~min}$ at $72^{\circ} \mathrm{C}$, as suggested by Chen et al. (2012). PCR products were separated in $1.5 \%$ formaldehyde agarose gel, with samples stained with GelRed (Invitrogen). DNA ladder TrackIt (Invitrogen) was used. The PCR products were purified with ExoSAP-it (Affymetrix Inc.), following the manufacturer's protocol. Purified reactions were submitted for sequencing at the UC-Davis Sequencing Facility. Sequence editing, inspection, and alignment were performed using the BioEdit program (version 7.0) (Hall 2004). Primers created for this study were designed with the open software Primer3 (v.0.4.0) (Koressaar and Remm 2007; Untergasser et al. 2012).

Allele-specific PCR assay. In this study, the sequence polymorphism analysis of the MfCYP51 gene revealed that all $M$. fructicola tebuconazole-resistant phenotypes had a single point mutation from glycine $(\mathrm{G})$ to alanine $(\mathrm{A})$ at the nucleotide position 1,492 , causing a change of $\mathrm{G}$ to a serine (S) at codon position 461 (G461S) of the gene MfCYP51. Based on this point mutation, primer pair MfgaF1/MfgaR1 (primer set 9) (Table 2) was designed to specifically prime the MfCYP51 gene of resistant isolates having this mutation. The forward primer MfgaF1 was designed to match the putative point mutation at the $3^{\prime}$ end of the primer. A base mismatch located at the fourth base position from the $3^{\prime}$ end was incorporated into the primer to enhance the specificity of the amplification (Kwok et al. 1990; Latorra et al. 2003). The primer pair was expected to generate a 178-bp PCR product from resistant isolates only. In total, 56 isolates sequenced for the MfCYP51 gene were used in this assay. PCR of $20 \mu \mathrm{l}$ in volume using the Accupower PCR premix Tube (Bioneer), contained $2 \mu \mathrm{l}$ of DNA template at $5 \mathrm{ng} / \mu \mathrm{l}$, $0.5 \mu \mathrm{l}$ of each primer pair at $10 \mu \mathrm{M}$, and $17 \mu \mathrm{l}$ of Dnase-free water. The thermocycler (Eppendorf Mastercycle) was programmed for $4 \mathrm{~min}$ at $95^{\circ} \mathrm{C} ; 32$ cycles of $30 \mathrm{~s}$ at $95^{\circ} \mathrm{C}, 30 \mathrm{~s}$ at $60^{\circ} \mathrm{C}$, and $2 \mathrm{~min}$ at $72^{\circ} \mathrm{C}$; followed by a final extension step of $10 \mathrm{~min}$ at $72^{\circ} \mathrm{C}$. The amplicons of each isolate from the allele-specific (AS)-PCR were analyzed by $1.5 \%$ agarose gel with samples stained with GelRed (Invitrogen) at $90 \mathrm{~V}$ for $50 \mathrm{~min}$. DNA ladder TrackIt (Invitrogen) was used. Primers created for this study were designed with the open software Primer3 (v.0.4.0) (Koressaar and Remm 2007; Untergasser et al. 2012).

\section{RESULTS}

Mona identification. No differences in fragment size between resistant and sensitive isolates were observed by the electrophoresis inspections (Fig. 1). All 58 isolates tested revealed a fragment size of $311 \mathrm{bp}$ when amplified with primer set 1 (Fig. 1, data shown for only 20 isolates). The restriction of PCR product with the endonuclease BsrBI into 236- and 140-bp fragments occurred only for the control Bmpc7 containing the Mona element (Fig. 1). Brazilian isolates showed no Mona, as confirmed by the sequence of the upstream region of MfCYP51 gene (Fig. 2).

Expression of the MfCYP51 and MfABC1 genes. The specificity of primer sets 2 and 3 for $M$. fructicola was confirmed after sequencing, showing the expected 176- and 120-bp PCR products, respectively (data not shown). The gene expression level obtained with fungicide treatment at $0.5 \mu \mathrm{g} / \mathrm{ml}$ in relation to dose 0 (control without fungicide) revealed that tebuconazole treatment induced the MfCYP51 gene expression level of isolates 213 at 9.09-fold and isolate 208 at 4.94-fold, whereas the expression of gene $M f A B C 1$ was induced for isolate 213 at 72.2-fold and for isolate 945 at 5.35-fold (Table 3). For all other tested isolates, the fold changes obtained for MfCYP51 and $M f A B C 1$ ranged from 0.01 to 2.85 and 0.06 to 2.41 , respectively (Table 3 ).

Partial sequencing of the MfCYP51 gene. Amplification of 59 isolates with primers sets 5, 6, 7, and 8 (Table 2) yielded a band size of $1,555 \mathrm{bp}, 125 \mathrm{bp}$ less than the original reported length (Chen et al. 2012; Schnabel and Dai 2004), including the two introns with 54 and 57 bp, respectively, as observed by Schnabel and Dai (2004). The sequences of the sensitive isolates 106 (GenBank accession

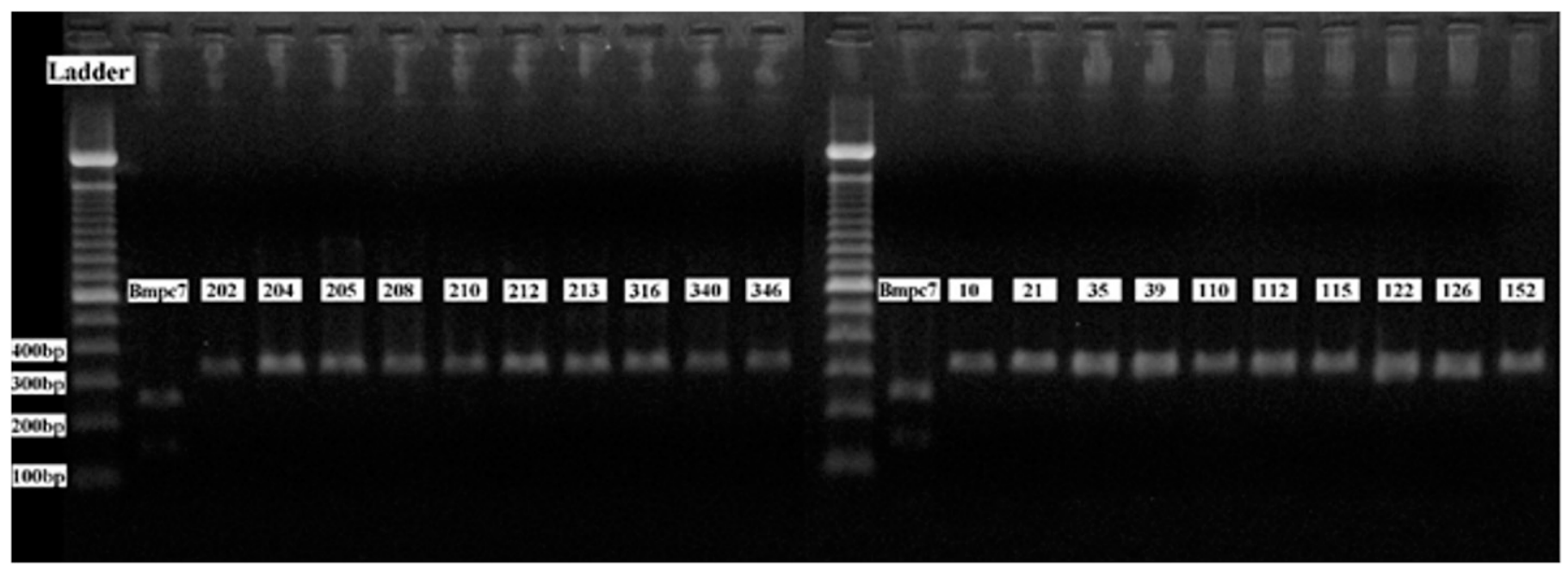

Fig. 1. Gel electrophoresis showing the polymerase chain reaction product digestion of Monilinia fructicola DNA by the enzyme BsrBI only for the positive reference (isolate Bmpc7 from Georgia). Isolates 202, 204, 205, 208, 210, 212, 213, 316, 340, 10, 115, and 152 are demethylation inhibitor (DMI) resistant whereas $21,35,39,110,112,122$, and 126 are DMI sensitive.

Bmpc7-Control
PR11-21
SP11-152
SP07-316
SP06-202
SP08-340
EU035301.1 Bmpc7

\begin{tabular}{|c|c|c|}
\hline TTGAAGAGATA & & TCCCATTTAAATTTATCGACTTTTCGCA \\
\hline TTGAAGAGATA & & TCCCATTTAAATTTATCGACTTTTCGCA \\
\hline TTGAAGAGATA & & TCCCATTTAAATTTATCGACTTTCGCA \\
\hline TTGAAGAGATA & & TCCCATTTAAATTTATCGACTTTCGCA \\
\hline TTGAAGAGATA & $40-b p$ & TCCCATTTAAATTTATCGACTTTCGC \\
\hline
\end{tabular}

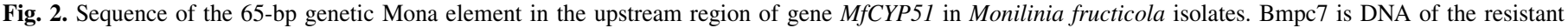
isolate used as reference. Restriction enzyme BsrBI identifies underlined sequence CCGCTC for Mona identification. 
KY542036) and 1099 (GenBank accession KY542037) and resistant isolates 807 (GenBank accession KY542038) and 802 (GenBank accession KY542039) are shown in Figure 3. A single nucleotide polymorphism (G to A), located at position 1,492 of MfCYP51 (Fig. 3A), revealed a putative amino acid change in position 461 (Fig. 3B), where $\mathrm{G}$ was replaced by $\mathrm{S}(\mathrm{G} 461 \mathrm{~S})$. Isolates $204\left(\mathrm{EC}_{50}>10 \mu \mathrm{g} / \mathrm{ml}\right), 208$ $\left(\mathrm{EC}_{50}>10 \mu \mathrm{g} / \mathrm{ml}\right), 210\left(\mathrm{EC}_{50}>10 \mu \mathrm{g} / \mathrm{ml}\right), 211\left(\mathrm{EC}_{50}=0.229 \mu \mathrm{g} / \mathrm{ml}\right)$, $212\left(\mathrm{EC}_{50}=0.406 \mu \mathrm{g} / \mathrm{ml}\right), 213\left(\mathrm{EC}_{50}>10 \mu \mathrm{g} / \mathrm{ml}\right), 311\left(\mathrm{EC}_{50}=0.2\right.$ $\mu \mathrm{g} / \mathrm{ml}), 336\left(\mathrm{EC}_{50}=0.1 \mu \mathrm{g} / \mathrm{ml}\right)$, and $344\left(\mathrm{EC}_{50}=0.15 \mu \mathrm{g} / \mathrm{ml}\right)$ were the only isolates with a resistant phenotype lacking the mutation G461S (Table 1). The other 29 isolates showing the resistant phenotype ( $\mathrm{EC}_{50}$ values of 0.131 to $>15.625 \mu \mathrm{g} / \mathrm{ml}$ ) carried the $\mathrm{G} 461 \mathrm{~S}$ mutation (Table 1). Regarding the sensitive isolate phenotypes $\left(\mathrm{EC}_{50}\right.$ values of 0.001 to $0.087 \mu \mathrm{g} / \mathrm{ml}$ ), the mutation was not present (Table 1). No other mutation on MfCYP51 resulting in amino acid change was found.

AS-PCR assay. At the annealing temperature of $60^{\circ} \mathrm{C}$, the AS assay amplified with primer set 9 resulted in a product of $178 \mathrm{bp}$ for all 29 isolates showing the G461S mutation. For the other 28 isolates without the G461S mutation, no amplification occurred (Fig. 4).

\section{DISCUSSION}

The cyp51 point mutations correlated with the resistance to specific DMI active ingredients, suggesting that different DMI are prone to selection for different mutations (Ziogas and Malandrakis 2015). In this study, a single point mutation of the gene MfCYP51 leading to an amino acid change from $\mathrm{G}$ to $\mathrm{S}$ at the codon position 461 was revealed as the main molecular mechanism conferring tebuconazole resistance in an M. fructicola population in Brazil. To the best of our knowledge, this is the first report of the G461S mutation causing DMI resistance in M. fructicola isolates. In China, the Y136F mutation was associated with UV-generated mutants of M. fructicola, resistant to DMI compound SYP-Z048, which was

TABLE 3. Relative expression of the genes MfCYP51 and MfABC1 in Monilinia fructicola treated with tebuconazole at $0.5 \mu \mathrm{g} / \mathrm{ml}$

\begin{tabular}{lccc}
\hline & & \multicolumn{2}{c}{$\begin{array}{c}\text { Normalized amount relative } \\
\text { to Mfactin } 2^{-\Delta \Delta C t a}\end{array}$} \\
\cline { 3 - 4 } Isolates & EC $_{50}$ values $(\mu \mathrm{g} / \mathrm{ml})$ & MfCYP51 & $M f A B C 1$ \\
\hline 15 & 0.48 & 1.37 & 0.06 \\
106 & 0.003 & 0.01 & 2.13 \\
204 & $>10$ & 1.12 & 1.4 \\
208 & $>10$ & 4.94 & 2.41 \\
210 & $>10$ & 1.14 & 0.03 \\
213 & $>10$ & 9.09 & 72.2 \\
349 & 0.01 & 0.46 & 0.006 \\
802 & 0.334 & 2.85 & 0.033 \\
807 & 1.164 & 0.6 & 0.13 \\
945 & 0.409 & 1.31 & 5.35 \\
\hline
\end{tabular}

a Reported values correspond to the fold expression obtained with fungicide at $0.5 \mu \mathrm{g} / \mathrm{ml}$ in relation to dose 0 (without fungicide) (Schmittgen and Livak 2008). also cross-resistant to propiconazole (Chen et al. 2012). Y136F and equivalent mutations at codon positions 134 and 137 appear as the most common CYP51 alteration but, to date, have never been associated with the tebuconazole usage (Becher and Wirsel 2012; Ziogas and Malandrakis 2015). The usage of different DMI active ingredients in China and Brazil explains the presence of G461S instead of Y136F in our isolates because, in Brazil, tebuconazole is the main DMI active ingredient used to control brown rot in stone fruit (May De Mio et al. 2011; Silva et al. 2011).

The same amino acid alteration observed in our isolates was discussed by Nikou et al. (2009) on affecting fungicide sensitivity in many fungal pathogens. More recently, Fujimura et al. (2016) listed the same G461S mutation in isolates of Podosphaera xanthii resistant to fungicides inhibiting ergosterol biosynthesis in cucumber. Similar mutations were also reported in Pyrenopeziza brassicae isolates with reduced tebuconazole sensitivity (Carter et al. 2014). In this same study, the authors revealed that isolates with a tebuconazole $\mathrm{EC}_{50}$ value of 0.23 to $0.79 \mu \mathrm{g} / \mathrm{ml}$ (similar to the range found in our study) carried the G460S mutation at the PbCYP51 gene. The G460S mutation reported by Carter et al. (2014) was equivalent to the G464S alteration found in Candida albicans, implicated in resistance to clinical azoles (Morio et al. 2010). It is still necessary to determine whether the substitution G461S observed in our study is an equivalent to G460S and G464S mentioned above. So far, we know that the $\mathrm{G}$ to $\mathrm{S}$ amino acid alterations at positions 460 and 461 were equivalent for the influenza $A$ and $B$ virus, resistant to neuraminidase inhibitors (Okomo-Adhiambo et al. 2013). The confirmation of this equivalency would also clarify the type of CYP51 heme environment perturbation occurring that results in an increased binding affinity for tebuconazole and reduced enzyme activity, as described by Kelly et al. (1999). Additionally, two other mutations associated with the usage of tebuconazole, not observed in our isolates, were described in Mycosphaerella graminicola (I138V/ MgCYP51) and Villosiclava virens (Y137H/VvCYP51) (Cools and Fraaije 2013; Wang et al. 2015).

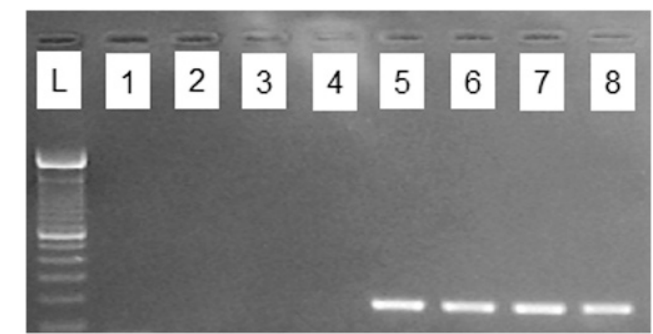

Fig. 4. Specificity of allele-specific polymerase chain reaction (AS-PCR) primer set 9 for detection of tebuconazole-resistant mutants of Monilinia fructicola. Amplification products were obtained using genomic DNA from mutants 802, 807, S45, and C23 (lanes 5 to 8, respectively) and wild-type (sensitive) isolates 1099, 106, C30, and C24 (lanes 1 to 4, respectively). L lane was loaded with 1-K DNA ladder (Invitrogen, Carlsbad, CA).

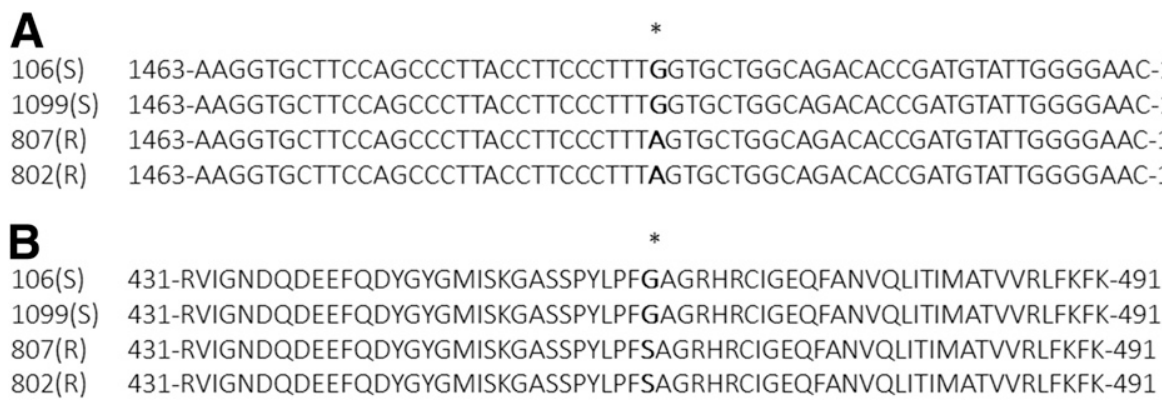

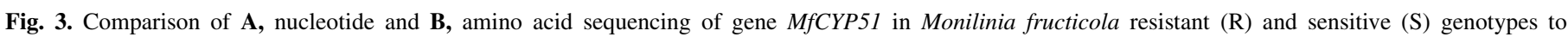

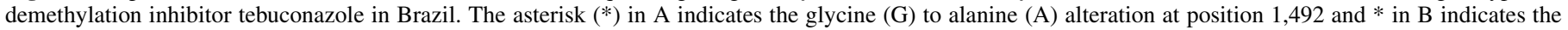
amino acid change of $\mathrm{G}$ to serine (S) at codon position 461 . 
In our study, G641S was absent in 9 of 38 isolates phenotyped as tebuconazole resistant: 6 from 2006 and 3 from 2008. A possible explanation is that the G461S mutation occurs only at a certain range of sensitivity, as observed for $M$. graminicola (Cools and Fraaije 2013; Leroux et al. 2007), P. brassicae (Carter et al. 2014), Erysiphe graminis f. sp. hordei (Délye et al. 1998), Erysiphe necator (Délye et al. 1997), and Cercospora beticola (Nikou et al. 2009). This would explain the mutation absence in four isolates from 2006 with $\mathrm{EC}_{50}$ value $>10 \mu \mathrm{g} / \mathrm{ml}$ but not for the 2008 isolate $340\left(\mathrm{EC}_{50}>\right.$ $10 \mu \mathrm{g} / \mathrm{ml}$ ), where the mutation was found. In order to clarify this observation, the tebuconazole sensitivity assay was repeated for isolates 204, 208, 210, 213, and 340 (with original $\mathrm{EC}_{50}$ values reported $>10 \mu \mathrm{g} / \mathrm{ml}$, Table 1) and isolates 212, 336, and 344 (with original $\mathrm{EC}_{50}$ values of 0.1 to $0.46 \mu \mathrm{g} / \mathrm{ml}$, Table 1). The results revealed that, for all isolates except 340 , the sensitivity increased to values commonly observed in DMI-sensitive isolates (data not shown). However, it is difficult to determine whether these isolates were not originally resistant or this shift back to sensitivity was caused by the storage effect, already described to occur in Monilinia fructicola (Lichtemberg et al. 2016b; Zhu et al. 2012).

Another possibility is that Brazilian isolates lacking G461S are affected by a different mechanism conferring tebuconazole resistance. The increased expression of MfCYP51 observed for isolates 213 (ninefold) and 208 (fivefold) indicates a possible secondary mechanism associated with DMI resistance. In Aspergillus parasiticus, elevated CYP51A gene expression were observed in DMI-resistant isolates lacking the G54W mutation (Doukas et al. 2012). As we observed, many other plant pathogens have been reported with similar CYP51 overexpression values (Carter et al. 2014; Doukas et al. 2012; Ma et al. 2006; Schnabel and Jones 2001). However, for most mentioned studies, overexpression has been associated with a different gene upstream insertion not found in our isolates. The Mona element, a 65-bp insert reported to promote MfCYP51 expression in M. fructicola (Luo and Schnabel 2008), was recently narrowed to a core element, within $20 \mathrm{bp}$, determining the DMI fungicide resistance through the upregulation of expression of the downstream MfCYP51 gene (Chen et al. 2017). This transposon-like Mona element was absent from the entire Brazilian population of $M$. fructicola investigated in this study, suggesting that another insert yet to be discovered could be the trigger of the MfCYP51 gene in our isolates. The absence of the Mona element in Brazilian isolates cannot be the result of possible loss due to storage or maintenance of isolates as performed by subculturing the isolates in vitro (Zhu et al. 2012). Furthermore, despite the CYP51 gene expression commonly found in pathogens with lower resistance levels than those resulting from site modification (Oliver and Hewitt 2014; Ziogas and Malandrakis 2015), our study showed the opposite, where isolates with $\mathrm{EC}_{50}>10 \mu \mathrm{g} / \mathrm{ml}$ resulted in overexpressed genes. Similar to our study, in C. beticola, Nikou et al. (2009) encountered a strong association between the overexpression of the $C Y P 51$ gene and the highly resistant phenotypes.

Despite the high $M f A B C l$ gene expression observed in isolate 213, we believe that this mechanism is not a determinant of DMI resistance of $M$. fructicola isolates from Brazil. The results observed for $M f A B C l$ were very inconsistent among the tested isolates, revealing that tebuconazole treatment was not able to induce gene expression uniformly for all resistant phenotypes. The ABC transporters involved in energy-dependent efflux of DMI have been described for A. nidulans (Del Sorbo et al. 2000), C. albicans (Prasad et al. 1995), Mycosphaerella graminicola (Zwiers et al. 2002), and Penicillium digitatum (Nakaune et al. 1998). In Monilinia fructicola, the role of $\mathrm{ABC}$ transporters as a mechanism which grants DMI resistance was shown only as a minor genetic determinant (Luo and Schnabel 2008; Schnabel et al. 2003).

In conclusion, DMI tebuconazole resistance in $M$. fructicola isolates from Brazil is related to the G461S target site mutation. The AS-PCR method developed in this study is a very important assay to quickly identify resistant genotypes based on a simple PCR that certainly will replace the time-consuming traditional method. This study not only reveals the mechanism of resistance responsible for altered tebuconazole sensitivity but also will guide future studies to better understand the DMI resistance dynamics in the $M$. fructicola population from Brazil. As a suggestion, future studies may include the following: (i) provide genetic evidence for G461S conferring DMI resistance in isolates from Brazil via genetic transformants; (ii) evaluate the equivalency among G461S, G460S, and G464S mutations; (iii) compare fitness between G461S mutants and wildtype isolates to determine whether a fitness penalty may influence the ability of the pathogen to develop a stable DMI-resistant population; (iv) DMI cross-resistance studies, to reveal whether the G461S mutation affects the binding affinity for other DMI-active ingredients; and (v) development of a real-time PCR method using the specific primer pair (primer set 9) designed here to quantify frequencies of resistant genotypes in large surveyed areas, as developed by Luo et al. (2007) in studies with E198A M. fructicola mutants resistant to benzimidazoles. All of these studies will certainly improve the establishment of DMI antiresistance strategies and prolong the useful life of the available chemical arsenal in Brazil.

\section{ACKNOWLEDGMENTS}

We thank G. Schnabel for providing us the Bmpc7 isolate genomic DNA; R. Puckett, J. Quattrini, and H. Avenot for their technical input; and the Coordenação de Aperfeiçoamento de Pessoal de Nível Superior (Capes) for the doctoral fellowship. This study was supported by CNPq grants 479041/ 2010-5 Universal/CNPq.

\section{LITERATURE CITED}

Altschul, S. F., Madden, T. L., Schäffer, A. A., Zhang, J., Zhang, Z., Miller, W., and Lipman, D. J. 1997. Gapped BLAST and PSI-BLAST: A new generation of protein database search programs. Nucleic Acids Res. 25: 3389-3402.

Amiri, A., Brannen, P., and Schnabel, G. 2010. Reduced sensitivity in Monilinia fructicola field isolates from South Carolina and Georgia to respiration inhibitor fungicides. Plant Dis. 94:737-743.

Batra, L. R. 1991. World Species of Monilinia (Fungi): Their Ecology, Biosystematics and Control. J. Cramer Press, Berlin/Stuttgart, Germany.

Becher, R., and Wirsel, S. G. 2012. Fungal cytochrome P450 sterol 14 $\alpha$ demethylase (CYP51) and azole resistance in plant and human pathogens. Appl. Microbiol. Biotechnol. 95:825-840.

Burnett, A., Lalancette, N., and McFarland, K. 2010. First report of the peach brown rot fungus Monilinia fructicola resistant to demethylation inhibitor fungicides in New Jersey. Plant Dis. 94:126.

Carter, H. E., Fraaije, B. A., West, J. S., Kelly, S. L., Mehl, A., Shaw, M. W., and Cools, H. J. 2014. Alterations in the predicted regulatory and coding regions of the sterol $14 \alpha$-demethylase gene (CYP51) confer decreased azole sensitivity in the oilseed rape pathogen Pyrenopeziza brassicae. Mol. Plant Pathol. 15:513-522.

Chen, F., Fan, J., Zhou, T., Liu, X., Liu, J., and Schnabel, G. 2012. Baseline sensitivity of Monilinia fructicola from China to the DMI fungicide SYPZ048 and analysis of DMI-resistant mutants. Plant Dis. 96:416-422.

Chen, F., Liu, X., Chen, S., Schnabel, E., and Schnabel, G. 2013. Characterization of Monilinia fructicola strains resistant to both propiconazole and boscalid. Plant Dis. 97:645-651.

Chen, S., Yuan, N., Schnabel, G., and Luo, C. 2017. Function of the genetic element 'Mona' associated with fungicide resistance in Monilinia fructicola. Mol. Plant Pathol. 18:90-97.

Cools, H. J., and Fraaije, B. A. 2013. Update on mechanisms of azole resistance in Mycosphaerella graminicola and implications for future control. Pest Manage. Sci. 69:150-155.

Cools, H. J., Hawkins, N. J., and Fraaije, B. A. 2013. Constraints on the evolution of azole resistance in plant pathogenic fungi. Plant Pathol. 62: 36-42.

Côté, M.-J., Tardif, M.-C., and Meldrum, A. J. 2004. Identification of Monilinia fructigena, M. fructicola, M. laxa, and Monilia polystroma on inoculated and naturally infected fruit using multiplex PCR. Plant Dis. 88: 1219-1225.

Crouse, J., and Amorese, D. 1987. Ethanol precipitation: Ammonium acetate as an alternative to sodium acetate. Focus 9:3-5.

Del Sorbo, G., Schoonbeek, H.-j., and De Waard, M. A. 2000. Fungal transporters involved in efflux of natural toxic compounds and fungicides. Fungal Genet. Biol. 30:1-15. 
Délye, C., Bousset, L., and Corio-Costet, M.-F. 1998. PCR cloning and detection of point mutations in the eburicol 14a-demethylase (CYP51) gene from Erysiphe graminis f. sp. hordei, a "recalcitrant" fungus. Curr. Genet. 34:399-403.

Délye, C., Laigret, F., and Corio-Costet, M.-F. 1997. A mutation in the 14 alpha-demethylase gene of Uncinula necator that correlates with resistance to a sterol biosynthesis inhibitor. Appl. Environ. Microbiol. 63:2966-2970.

Doukas, E. G., Markoglou, A. N., Vontas, J. G., and Ziogas, B. N. 2012. Effect of DMI-resistance mechanisms on cross-resistance patterns, fitness parameters and aflatoxin production in Aspergillus parasiticus Speare. Fungal Genet. Biol. 49:792-801.

Elmer, P., Braithwaite, M., and Saville, D. 1992. Changes in triforine sensitivity in populations of Monilinia fructicola from Hawkes Bay orchards. Pages 138-140 in: Proc. N. Z. Plant Prot. Conf. N. Z. Plant Prot. Soc.

Fujimura, M., Banno, S., Kamei, M., Ishigami, Y., and Tsukada, Y. 2016. Detection and monitoring of fungicide resistance in plant pathogens using pyrosequencing. Jpn. J. Pestic. Sci. 41:78-87.

Hall, T. 2004. BioEdit version 7.0. 0. Online publication. Distributed by the author.

Hamamoto, H., Hasegawa, K., Nakaune, R., Lee, Y. J., Makizumi, Y., Akutsu, K., and Hibi, T. 2000. Tandem Repeat of a Transcriptional Enhancer Upstream of the Sterol $14 \alpha$-Demethylase Gene (CYP51) in Penicillium digitatum. Appl. Environ. Microbiol. 66:3421-3426.

Kelly, S., and Kelly, D. 2013. Microbial cytochromes P450: Biodiversity and biotechnology. Where do cytochromes P450 come from, what do they do and what can they do for us? Philos. Trans. R. Soc. B 368: Article 20120476. doi:10.1098/rstb.2012.0476

Kelly, S. L., Lamb, D. C., Loeffler, J., Einsele, H., and Kelly, D. E. 1999. The G464S amino acid substitution in Candida albicans sterol $14 \alpha$-demethylase causes fluconazole resistance in the clinic through reduced affinity. Biochem. Biophys. Res. Commun. 262:174-179.

Koressaar, T., and Remm, M. 2007. Enhancements and modifications of primer design program Primer3. Bioinformatics 23:1289-1291.

Kwok, S., Kellogg, D., McKinney, N., Spasic, D., Goda, L., Levenson, C., and Sninsky, J. 1990. Effects of primer-template mismatches on the polymerase chain reaction: Human immunodeficiency virus type 1 model studies. Nucleic Acids Res. 18:999-1005.

Latorra, D., Campbell, K., Wolter, A., and Hurley, J. M. 2003. Enhanced allele-specific PCR discrimination in SNP genotyping using $3^{\prime}$ locked nucleic acid (LNA) primers. Hum. Mutat. 22:79-85.

Leroux, P., Albertini, C., Gautier, A., Gredt, M., and Walker, A. S. 2007. Mutations in the CYP51 gene correlated with changes in sensitivity to sterol $14 \alpha$-demethylation inhibitors in field isolates of Mycosphaerella graminicola. Pest Manage. Sci. 63:688-698.

Leroux, P., and Walker, A.-S. 2013. Activity of fungicides and modulators of membrane drug transporters in field strains of Botrytis cinerea displaying multidrug resistance. Eur. J. Plant Pathol. 135:683-693.

Lichtemberg, P. S. F., Primiano, I., Fischer, J., Glienke, C., Amorin, L., and May de Mio, L. 2016a. Resistência de Monilinia spp. aos fungicidas dos grupos dos inibidores da demetilação (IDM), dos inibidores da quinona externa (IQE) e dos metilo benzimidazol carbamatos (MBC). Rev. An. Patol. Plantas 24:145-173.

Lichtemberg, P. S. F., Zeviani, W. M., Michailides, T. J., and May De Mio, L. L. 2016b. Comparison of the sensitivity of Monilinia fructicola isolates to tebuconazole in Brazil using three methods. Can. J. Plant Pathol. 38: 55-63.

Livak, K. J., and Schmittgen, T. D. 2001. Analysis of relative gene expression data using real-time quantitative PCR and the $2^{-\Delta \Delta C T}$ method. Methods 25 : 402-408.

Luo, C.-X., Cox, K. D., Amiri, A., and Schnabel, G. 2008. Occurrence and detection of the DMI resistance-associated genetic element 'Mona' in Monilinia fructicola. Plant Dis. 92:1099-1103.

Luo, C.-X., and Schnabel, G. 2008. The cytochrome P450 lanosterol 14 $\alpha$ demethylase gene is a demethylation inhibitor fungicide resistance determinant in Monilinia fructicola field isolates from Georgia. Appl. Environ. Microbiol. 74:359-366.

Luo, Y., Ma, Z., and Michailides, T. J. 2007. Quantification of allele E198A in beta-tubulin conferring benzimidazole resistance in Monilinia fructicola using real time PCR. Pest Manage. Sci. 63:1178-1184.

Lupetti, A., Danesi, R., Campa, M., Tacca, M. D., and Kelly, S. 2002. Molecular basis of resistance to azole antifungals. Trends Mol. Med. 8:76-81.

Ma, Z., Proffer, T. J., Jacobs, J. L., and Sundin, G. W. 2006. Overexpression of the $14 \alpha$-demethylase target gene (CYP51) mediates fungicide resistance in Blumeriella jaapii. Appl. Environ. Microbiol. 72:2581-2585.

Mann, P. A., Parmegiani, R. M., Wei, S.-Q., Mendrick, C. A., Li, X., Loebenberg, D., DiDomenico, B., Hare, R. S., Walker, S. S., and McNicholas, P. M. 2003. Mutations in Aspergillus fumigatus resulting in reduced susceptibility to posaconazole appear to be restricted to a single amino acid in the cytochrome P450 14 $\alpha$-demethylase. Antimicrob. Agents Chemother. 47:577-581.

May De Mio, L. L., Luo, Y., and Michailides, T. J. 2011. Sensitivity of Monilinia fructicola from Brazil to tebuconazole, azoxystrobin, and thiophanate-methyl and implications for disease management. Plant Dis. 95:821-827.

Morio, F., Loge, C., Besse, B., Hennequin, C., and Le Pape, P. 2010. Screening for amino acid substitutions in the Candida albicans Erg11 protein of azolesusceptible and azole-resistant clinical isolates: New substitutions and a review of the literature. Diagn. Microbiol. Infect. Dis. 66:373-384.

Nakaune, R., Adachi, K., Nawata, O., Tomiyama, M., Akutsu, K., and Hibi, T. 1998. A novel ATP-binding cassette transporter involved in multidrug resistance in the phytopathogenic fungus Penicillium digitatum. Appl. Environ. Microbiol. 64:3983-3988.

Nikou, D., Malandrakis, A., Konstantakaki, M., Vontas, J., Markoglou, A., and Ziogas, B. 2009. Molecular characterization and detection of overexpressed C-14 alpha-demethylase-based DMI resistance in Cercospora beticola field isolates. Pestic. Biochem. Physiol. 95:18-27.

Okomo-Adhiambo, M., Sleeman, K., Lysén, C., Nguyen, H. T., Xu, X., Li, Y., Klimov, A. I., and Gubareva, L. V. 2013. Neuraminidase inhibitor susceptibility surveillance of influenza viruses circulating worldwide during the 2011 Southern Hemisphere season. Influenza Other Respir. Viruses 7: 645-658.

Oliver, R. P., and Hewitt, H. G., eds. 2014. Fungicides in Crop Protection, 2nd ed. CAB International, Oxfordshire, UK.

Prasad, R., De Wergifosse, P., Goffeau, A., and Balzi, E. 1995. Molecular cloning and characterization of a novel gene of Candida albicans, CDR1, conferring multiple resistance to drugs and antifungals. Curr. Genet. 27: 320-329.

Schmittgen, T. D., and Livak, K. J. 2008. Analyzing real-time PCR data by the comparative CT method. Nat. Protoc. 3:1101-1108.

Schnabel, G., Bryson, P. K., Bridges, W. C., and Brannen, P. M. 2004. Reduced sensitivity in Monilinia fructicola to propiconazole in Georgia and implications for disease management. Plant Dis. 88:1000-1004.

Schnabel, G., and Dai, Q. 2004. Heterologous expression of the P450 sterol $14 \alpha$-demethylase gene from Monilinia fructicola reduces sensitivity to some but not all DMI fungicides. Pestic. Biochem. Physiol. 78:31-38.

Schnabel, G., Dai, Q., and Paradkar, M. 2003. Cloning and expression analysis of the ATP-binding cassette transporter gene $M f A B C 1$ and the alternative oxidase gene MfAOX1 from Monilinia fructicola. Pest Manage. Sci. 59: 1143-1151.

Schnabel, G., and Jones, A. L. 2001. The 14 $\alpha$-demethylasse (CYP51A1) gene is overexpressed in Venturia inaequalis strains resistant to myclobutanil. Phytopathology 91:102-110.

Shapiro, R. S., Robbins, N., and Cowen, L. E. 2011. Regulatory circuitry governing fungal development, drug resistance, and disease. Microbiol. Mol. Biol. Rev. 75:213-267.

Silva, S., Kohls, V., Manica-Berto, R., Rigatto, P., and Rombaldi, C. 2011. Apropriação tecnológica da produção integrada de pêssego na região de Pelotas no estado do Rio Grande do Sul. Cienc. Rural 41:1667-1673.

Untergasser, A., Cutcutache, I., Koressaar, T., Ye, J., Faircloth, B. C., Remm, M., and Rozen, S. G. 2012. Primer3-New capabilities and interfaces. Nucleic Acids Res. 40:e115.

Villani, S. M., and Cox, K. D. 2011. Characterizing fenbuconazole and propiconazole sensitivity and prevalence of 'Mona' in isolates of Monilinia fructicola from New York. Plant Dis. 95:828-834.

Wang, F., Lin, Y., Yin, W.-X., Peng, Y.-L., Schnabel, G., Huang, J.-B., and Luo, C.-X. 2015. The Y137H mutation of VvCYP51 gene confers the reduced sensitivity to tebuconazole in Villosiclava virens. Sci. Rep. 5: Article 17575. doi:10.1038/srep 17575

Wyand, R., and Brown, J. 2005. Sequence variation in the CYP51 gene of Blumeria graminis associated with resistance to sterol demethylase inhibiting fungicides. Fungal Genet. Biol. 42:726-735.

Zehr, E. I., Luszcz, L. A., Olien, W. C., Newall, W., and Toler, J. E. 1999. Reduced sensitivity in Monilinia fructicola to propiconazole following prolonged exposure in peach orchards. Plant Dis. 83:913-916.

Zhu, F., Bryson, P. K., and Schnabel, G. 2012. Influence of storage approaches on instability of propiconazole resistance in Monilinia fructicola. Pest Manage. Sci. 68:1003-1009.

Ziogas, B., and Malandrakis, A. 2015. Sterol biosynthesis inhibitors: C14 demethylation (DMIs). Pages 199-216 in: Fungicide Resistance in Plant Pathogens. H. Ishii and D. Hollomon, eds. Springer, Tokyo.

Zwiers, L.-H., Stergiopoulos, I., Van Nistelrooy, J. G., and De Waard, M. A. 2002. ABC transporters and azole susceptibility in laboratory strains of the wheat pathogen Mycosphaerella graminicola. Antimicrob. Agents Chemother. 46:3900-3906. 